\title{
The Istanbul Biennial and the reproduction of the urban public space
}

\author{
Ceren Özpınar, University of Brighton
}

\begin{abstract}
Initiated by the Istanbul Foundation for Culture and Arts in 1987, the Istanbul Biennial is the product of a period in which many cities of the Global South started their own biennials.
\end{abstract}

With the participating 'star' curators and artists, the Biennial gradually sparked attention from the international art world. Yet, it also received occasional negative responses from the local art world. Critics stressed the problematic relationship of the Biennial with one of the key players behind the urban regeneration process in the city. Designed as a wide-reaching contemporary art event in a city of an enormous scale, a vast population and contested histories, the Biennial was set in a range of venues throughout Istanbul over the years. This not only lea the Biennial to continuously reframe Istanbul through the selected new locations and unwittingly reproduce the urban public space but also to redefining the way in which the visitors relate to both the city and the event per se. This article discusses the re-organization of the public space by the Istanbul Biennial in the backdrop of contemporary art practices, the art historical discourse and the changing social and political context of the last 30 years in Turkey by drawing on the theories of Michel de Certeau, Chantal Mouffe and Sibel Yardimci among others. 
Keywords: Istanbul Biennial, Urban Public Space, City, Exhibition venues, Visitors,

\section{Contemporary Art, Gentrification.}

Istanbul Foundation for Culture and Arts (IKSV), a non-profit and non-governmental organization, initiated the Istanbul Biennial in 1987 with a view to building an international cultural network and a contact point for artists and cultural practitioners in Istanbul. IKSV, founded by one of the biggest industrial companies in Turkey, the Eczacıbaşı in 1973, which has also been organizing music, jazz, film and theatre festivals in Istanbul for many years, has been a catalyst for cultural events in the city. It has not only been contributing to the wider cultural production in the country by supporting the academia in debating national cultural policies but also endorsing artists and encouraging the production of new works (IKSV Official Website 2017; Özpınar et al. 2011: 213-20).

Celebrating its 30th anniversary in 2017, the Istanbul Biennial appears to be the product of a period in which many cities of the Global South, aligning with 'the postcolonial turn' in humanities and arts, started their own biennials. Yet, this period also indicated the dissemination of neo-liberal globalization and a tendency towards the 'festivalization' that often manifested itself worldwide in the form of biennials (Madra 2006: 529; Demos 2009). However, the new biennials aimed at challenging the dominance of the biennials and by 
extension the art institutions, which have been held for decades in Western Europe and North America, and to bring a new perspective to the centre-periphery opposition in the art world. Alongside the biennial in Istanbul, cities such as Havana (1984), Dakar (1992), Sharjah (1993) and Taipei (1998) initiated their biennial in this period.

As one of the biennials such as Gwangju, Lyon or Montreal biennials, according to Chin TaoWu's (2010) biennial categories, the Istanbul Biennial appears to subscribe to the biennial category of 'city-based events'. What is interesting is that although named after a city, only a small number of city-based biennials do not have a dedicated exhibition venue. Despite early attempts of designating a permanent place, this short list includes the Istanbul Biennial, and Berlin and Sharjah biennials. Thus, although some places such as the warehouses were employed for more than one edition, the Istanbul Biennial has made use of a variety of locations in the city over three decades by amending venues in every edition.

This article assesses the significance of the venues and locations of the Istanbul Biennial to the extent to which they organize, reproduce and change the way both the audience and diverse urban groups relate to the urban public space and the city of Istanbul. A full discussion of the venues of the Istanbul Biennial is beyond the scope of this study, although a general idea of the imagery that has been communicated through the venues and locations will be discussed as it is critical to enhancing our understanding of how they are situated for and against the viewer. Before proceeding to an examination of these questions, it is 
necessary to address the ways in which the Istanbul Biennial is positioned in the Turkish art history to understand the meaning of the event in the construction of contemporary art narratives.

A significant aspect of the Biennial for art history is that its first editions adopted the national pavilion system of the Venice Biennial and only after the third biennial it turned to the now well-established international exhibition system by assigning a new curator in each edition. The first three editions were organized under the artistic direction of cultural figures native to Istanbul, Beral Madra and Vasif Kortun, and they indeed showed the ways in which the idea of the biennial developed and adapted by the curators and IKSV for the existing art world in Istanbul. Well connected with the wider art world, both curators also had experience with the art scene of Istanbul for many years before the Biennial. Their memories of those days highlight a hands-on approach to the coordination of the event; because of having to deal with basic communication technologies of those days and being on a small budget and a tight timeframe, they drew on previously constructed networks and affiliations (Kortun 2018: 2233; Madra 2003: 16-17). The event was not called 'Biennial' until the third edition and, to an extent, had been a collaborative project between the organizers and the artists. Although the third edition had changed the exhibition system and assigned the task of organizing the Biennial to the vision of a single person, it was not until the fourth edition that the Biennial assumed an institutional form. 
The art historical narratives of Turkey often signalled this transformation as a milestone as the transition to the international exhibition system in the subsequent biennials has not only brought the stardust of the widely known curators of the art world to Istanbul, including René Block and Rosa Martinez and their diverse expertise in exhibition-making, but has also shaped the way in which the art histories narrate the emergence of contemporary art in Turkey. It is a widely held view that Turkey's success in cultural development would be assessed by the imagery that positions the 'West' as a standard (Ahiska 2005: 40). The narratives thus often mark the Istanbul Biennial, along with a few other exhibitions of the 1980s such as A Cross Section of Avant-garde Turkish Art (1987 and 1988), as the milestone in the advent of contemporary artistic practices in Turkey (Özpinar 2016: 42-3). More importantly, the transition to the star-curator and international representation system appears to be seen as the main catalyst for the development of contemporary art. While this view allows the narratives to construct the story of contemporary art in Turkey around the Biennial, it reveals how the global art world and, by extension, the idea of progress prevails in the writing of national art histories.

\section{The view from the panorama-city}

In his seminal study, Arjun Appadurai (1996: 33-37) identifies 'artscape' as the uninterrupted cultural flow of artists, curators and critics travelling regularly across the world to visit events. Having had its share of both 'artscape' and stardust, while the Istanbul 
Biennial has gradually become more important for narratives and the local art world, it appeared to assume a rather institutional form and discourse. This has especially become evident in the ways in which the Biennial communicated with the world while carving a new image of Istanbul. In her pivotal study of the Istanbul Biennial, Sibel Yardımc1 (2005) points out that the reflections of the change on discourse and the image created for Istanbul through the Biennial were mainly based on the fact that the city was founded across two continents: Europe and Asia. Istanbul was portrayed as a bridge or a door that connects not only the two continents but also the two lands that represent opposing, if not incorporating, cultures, concepts and values, such as the East and the West, the Byzantine and the Ottoman and the other binaries by association - the new and the old, the developed and the undeveloped, the white and the non-white (Yardımc1 2005: 72-76). In a sense, the Biennial, against its critical outset, has produced and reproduced the colonial imagination in the representation of the city. According to Yardımc1, as many other festivals organized by IKSV, the Biennial has communicated an image of "'oriental” Istanbul' particularly by representing the city with its mosques and palaces in the form of a silhouette, while merging 'its socio-historical heritage with a western techno-economic level of material development, familiarity with culture and adherence to secularism' (Yardımc1 2007: 5) (Figure 1).

Correspondingly, also the curatorial strategies of display seemed to often serve this purpose throughout the years. Many editions of the Istanbul Biennial opted for displaying artworks in 
buildings that were either formerly used during the Ottoman Empire, such as the Imperial Kitchens and the Imperial Mint, or in the Byzantine era, including the Basilica Cistern and the Hagia Eirene Church, located in the area of Istanbul that is known as the historic peninsula. In addition to the visual effect intended by creating a clash between the ancient and the contemporary (Madra 2003: 17), as Yardımc1 suggests, the Biennial also reinforced an orientalized image of the city on visitors, the one that marks Istanbul as a place that bridges different continents, empires, cultures and religious beliefs (Figure 2). This was clearly evident, for example in the display of the installations of the artists Michelangelo Pistoletto (b. 1933) and Qin Yufen (b. 1954) in Hagia Eirene in the first and fourth editions, respectively.

In the following years, the Biennial curators oftentimes decided against choosing the locations on the historic peninsula as exhibition venues. However, much of the strategies of display and selected artworks frequently led to portrayal of the city as a bridge anyway. For instance, the fourth Istanbul Biennial curated by Block in 1995, although openly challenged the idea of orientalizing Istanbul with its title ORIENT-ATION and conceptual framework, presented the city as, what Michel de Certeau calls, a 'panorama-city' by particularly choosing the biennial venues on the shores of Bosporus - the natural strait that cuts across the city creating its famous landscape (Certeau 1984: 93; Özpinar 2011: 271). Amongst these locations was one of the warehouses of the former Istanbul seaport, in which, while 
reinforcing the image of the city as a 'bridge', in the words of Block, the Biennial exhibitions aesthetically presented the city by framing the landscape within its large windows (1995) and formed a background for installations. The artist Gülsün Karamustafa’s (b. 1943) work called Neworientation, which was placed just by one of those large windows, is a good illustration of this, especially considering the reflection of the work overlapping with the view of Bosporus in media photos (Figure 3). Although de Certeau takes the view from the top of the World Trade Center as his point of departure, his description of the panorama-city as an urban landscape that, while offering an all-around vista, reflects the way in which the warehouse windows distance the viewer from the city, a 'theoretical', visual simulacrum, a picture, he defines, 'whose condition of possibility is an oblivion and a misunderstanding of practices' (Certeau 1984: 93). While de Certeau casts the viewer as a 'voyeur-god' with a totalizing eye, the way it relates to the landscape remains abstract. In this respect, the Biennial converts the city into an eye-pleasing image for visitors, an image that is attractive yet elusive, which is to be repeatedly consumed but subsequently forgotten (Özpınar 2011: 271-72).

Similar uses of the landscape in other editions of the Biennial include the light-space work created by the artist James Turrell (b. 1943), albeit called off last minute (Pelvanoğlu 2015), at the Leander's Tower -a Byzantine structure situated on a lone-standing small island in Bosporus - and Alberto Garutti's (b. 1948) installation of lights on the Bosporus Bridge - 
both planned for the seventh Biennial in 2001, which was curated by Yuko Hasegawa (Figure 4). Especially Garutti's installation To Those Born Today (2000) is worth mentioning in this context. The work was premised on a subtle play of lights, which, although designed as an attempt to reach out to the residents of the city, remained largely unclear to viewers: the actual lights of the Bridge were becoming brighter each time a new baby was born in the city, and similarly, the uncanny photographs of, what Pınar Üner Yılmaz (2016) calls, the 'imaginary' works of the fourteenth edition, which was curated by Carolyn ChristovBakargiev in 2015, including the radar antenna in the deserted far-out Riva Beach or Pierre Huyghe's (b. 1962) Abyssal Plain on an unpopulated island just off the coast of Istanbul, albeit inaccessible, distributed to the media. Acting as distant, unreachable and aesthetic images, these artworks rather reflect the Biennial's problematic reconstructions of urban landscapes for the promotion of the city.

In an investigation of the contested urban imaginary of Istanbul created by the cultural economy, performing a case study of the Istanbul Museum of Modern Art and the Istanbul Biennial, Ayşe N. Erek and Ayşe H. Köksal (2014) argue that the Biennial reinforces ‘city’s contemporary art as an aspect and signifier of its global viability and competitiveness in transnational markets' (Erek and Köksal 2014: 313). This also explains why the media images created for the ninth edition of the Biennial were also of panoramic quality, for which the photographer Gabriele Basilico (1944-2013) was specifically invited, proposing 
beguiling views of the modern, industrialized Istanbul (Figure 5). Banu Karaca notes that art critics often referred to the object of these photographs, the 'modern' locations, as 'more impressive, if not spectacular, than the artworks themselves' (2010: 239). The project called A Tribute to Safiye Behar (2005), created by the artist Michael Blum (b. 1966) for this edition of the Biennial, which was held in 2005 and curated by Charles Esche and Vasif Kortun, was subscribing to a similar image production of the city. Narrating the story of the fictional character named Safiye Behar, a Marxist Feminist Istanbulite woman of Jewish origins who supposedly lived in the early 1900s, Blum reconstructed the flat that he imagined for Behar in the then-recently renovated Deniz Palas, a block of flats fashioned in Art Nouveau style overlooking another famous view of Istanbul - the Golden Horn, the horn-shaped waterway that extends from the historic peninsula towards Eyüp. While Deniz Palas later turned into the headquarters of IKSV, the photographs that document Blum's imaginary museum of Behar constituted an evident praise of the beauty of both the city and the Golden Horn. Especially Behar's living room, which was conveniently placed in front of a large window, rather complicated as to what was conveyed with them - the view of the Golden Horn at sunset or Blum's display (Figure 6).

The Golden Horn indeed functioned as another major tourist attraction for the Biennial, in which the intersection of the two different cultural and religious pasts of the city is embodied in Byzantine churches and Ottoman mosques and the initial industrial expansion of the 
Ottoman capital is visible. In addition to the previously mentioned Deniz Palas, other places on the shores of this former industrial area were also employed as biennial venues in the past. Among these, the former hat factory on the Golden Horn that was renovated for the third Biennial in 1992 was indeed considered by IKSV for both a permanent biennial venue and a modern art museum but was later decided against for a variety of reasons (Karaca 2010: $242)^{1}$ (Figure 7). Located in close proximity to major tourist attractions including the Eyüp Sultan Mosque and the Pierre Loti hilltop, whose view once was the favourite writing spot of the French novelist Loti (1850-1923), were also some of the campus buildings of the Istanbul Bilgi University and the former Küçük Mustafa Paşa Hammam in both the fourteenth (2015) and fifteenth editions (2017) (Figure 8). It seems possible to explain these cases with effects of the rise of the city-based cultural tourism, cultural heritage and art and the promotional events such as the European Capital of Culture (2010) in Istanbul, which has thus often instrumentalized the Biennial to attract tourists. Moreover, it appears that the Biennial itself has promoted the same goal as it has instrumentalized not only the art that was displayed but also the urban landscape through the specific uses of chosen venues and locations.

\section{Encounters with art in the urban public space}

The venue and location choices also bring up the question of the public sphere to debate and the extent to which the Biennial regulates the urban public space, visitors' relation to the city 
and their exhibition experience. With respect to public space, in his seminal theory, which traces the development of the public space through the centuries, Jürgen Habermas (1991: 27-29) defines the public spaces as a 'sphere of private people come together as a public, [...] to engage [the public authorities] in a debate over the general rules governing relations in the basically privatized but publicly relevant sphere of commodity exchange and social labor'. Although the Habermasian idea of public space points out to places where ideas and experiences of urban groups are expressed, re-produced, explored, shared, discussed and spread, questions have been raised about the impact of capitalism on the 'political function' of public space. However, in her study of the public space, Chantal Mouffe (2007) showed that while Habermasian idea of public space relied on 'consensus', to 'contribute to questioning the dominant hegemony' and 'to unveil all that is repressed by the dominant consensus', agonism, i.e. political conflict, must prevail in public spaces, in which 'critical art' can play an important role (Mouffe 2007). Yet, in his investigation on the notion of public space in Turkey, Uğur Tanyeli (2007) notes that there is little consensus about what public space actually means in Turkey. Similar to the way in which Habermas (1991: 27) describes the traditional uses of 'public' and 'public place', Tanyeli (2007) observes that also in Turkey 'public buildings', such as (public) universities, libraries, museums and hospitals, are not really public, or, open to all, but they are 'state institutions' that represent the 'public authority'. Similarly, according to Tanyeli (2007), urban areas such as parks, squares and 
streets where diverse urban groups share ideas, are controlled spaces that belong to and disrupted by the public authority in Turkey (Özpınar 2011: 280) (Figure 9).

The Istanbul Biennial illustrates this point clearly. How are we to understand the rare use of urban public spaces by a city-based event such as the Biennial for its exhibitions? Among the venues that the Biennial has used a large portion are 'public' spaces under the governmental or municipal control, or, privately owned. That the Biennial only rarely made use of 'open' public spaces, including train stations, squares and streets, is problematic for a variety of reasons. First and clearly, the use of privately owned places or the 'public' places that represent the authority restricts the possibility of unexpected, free, unique encounters of diverse audiences with art (Yardımc1 2007: 53-4). These places limit the Biennial's potentials of interaction by secluding and isolating art in designated spaces while maintaining the core target audience and, if not inadvertently, excluding the participation of 'others'. A clear attempt to change this was made by the thirteenth edition, which aimed to develop the Biennial in 2013 in urban public spaces. Yet, although the curator Fulya Erdemci suggested 'an exhibition in a dialogue with the city', this did not appear to be the case (Erdemci cited in Coates 2014: 126). In the backdrop of the civil unrest created by the Gezi Park protests in summer, the Biennial backed up on the initial proposal and retreated from the public space. Moreover, it was clear that Erdemci's framing of the notion of public space suffered from serious weaknesses and has been subjected to considerable criticism (Anon. 2013; Özpınar 
2013: 110-12). In her conceptual framework, Erdemci reveals the venues to be used by the Biennial as $[\ldots]$ public buildings left temporarily vacant by urban transformation. These may include courthouses, schools or military structures, post offices, former transportation hubs such as train stations, ex-industrial sites such as warehouses, dockyards and the very contested Taksim Square and Gezi Park. Furthermore, the hallmarks of current urbanism such as shopping malls, hotels and office-residential towers are considered as sites for artistic interventions (13th Istanbul Biennial 2013).

The first question that needs to be asked is in what ways the privately owned 'hallmarks of current urbanism' could be constituted as public spaces. Despite the alluded possibility of making 'interventions', what kind of participation can we expect from viewers in those spaces, which clearly are the perfect embodiments of global capitalism and consumerism? Moreover, Erdemci failed to recognize the controversies of employing vacant, old 'public' buildings. If it was realized, this attempt may not only have served to advance the gentrification of those areas on the possible grounds of the new flow of upper/middle-class audiences that the Biennial attracts but may have also further detached the viewers almost as if in a 'white cube' environment since those were remote, inaccessible buildings that were cut off from the critical-political reality of everyday life (Özpınar 2013: 110). By contrast, the fifth edition that was organized in 1997 showed how the involvement of the 'open' public spaces can change and expand the participation of diverse audiences, albeit 
temporarily. The Kültür project, which was designed by the artist Ursula Biemann's (b. 1955) in collaboration with sociologists, NGOs and researchers from Istanbul, addressed the living conditions of the residents of Karanfilköy, an inner-city slum near Bosporus (Biemann 1997). After the authorities demolished most of the self-made houses in the area, the open-air night forum that Biemann held during the Biennial with the participation of the residents demonstrated the possibilities that the 'open' public spaces had to offer. Other examples of the use of 'open' public space were the installations in city squares and streets, including those of Metin Deniz (b. 1940) in Sultanahmet Square in the second edition in 1989, Rogelio López Cuenca (b. 1959) on various streets, Cildo Meireles (b. 1948) on Istiklal Street and Doris Salcedo (b. 1958) in Karakoy district, all three displayed in the eight edition curated by Dan Cameron in 2003 (Figure 10).

In this sense, the interaction with the Biennial often promises not only unexpected encounters with the city but also a cultural and social exchange with residents. Also notable is that, because of Istanbul's entangled urban structuring, most of the biennial locations were centrally located in the city. What this meant for the target audience of the Biennial was that they were encouraged to stroll the city while exploring different locations through their own walking experience. As the ninth and partly the fourteenth edition were set on the axis of Galata and Taksim, their respective visitors were presented with the opportunity of involving with the city first-hand (Özpınar 2011: 275-76). While the personal experience of the routes 
to the venues constitutes the city in the eyes of the visitors, in return, the visitors make up the paths and the urban space of the city. As de Certeau observes (1984: 97), 'pedestrian movements form one of these "real systems whose existence in fact makes up the city" in that their footsteps, as an 'innumerable collection of singularities', form intertwined paths [that] give their shape to spaces [and] weave places together' (Certeau 1984: 97; Kolatan 1995: 46-47). By contrast, that both editions marked the biennial venues to facilitate the experience of visitors - the ninth by highlighting the buildings with colour magenta, the fourteenth by a pale-coloured biennial flag, it became a mechanism that tipped the audience off about the places that they were about the encounter. Furthermore, this led the visitors to travel within a predefined limited area, perhaps even to follow one of the suggested routes by the Biennial, which in most cases, intrinsically excluded wandering into the wider urban space.

Certainly, interacting with the urban space and everyday life of the city works both ways as it suggests the accidental, if not passive, participation of the residents. People who pass by the exhibition venues are thus accorded with the possibility of casually becoming a biennial visitor. Although previously granting the contemporary art experience only to the ticketholders, the Biennial has been free since the thirteenth edition, which was curated by Fulya Erdemci in 2013. As Matthew Carmona suggests, often adopted by institutions such as museums, restricting the entrance to a ticket and an entry fee not only dictates financial 
exclusion but also social eligibility, which makes those outside that category to be doubted and alienated (Carmona 2010: 138). Indeed this alteration meant a symbolic gesture and a milestone in the attempts of widening the audience participation as the visitor segmentation set by the ticket prices and rules has been thus annulled. In fact, it is indispensable to not consider the impact of diverse urban populations on the Biennial and vice versa (Figure 11). In this respect, centrally locating the Biennial also meant often limiting the outreach and the encounters of diverse segments of the society with art. Although a couple of previous editions attempted to tackle this, they failed to acknowledge the wide scope and cultural differences in the city. This can be seen in the case of the tenth edition that was curated by Hou Hanru in 2007, in which, in addition to the three central venues in three different large districts, a few far-out spaces were employed with a view to spreading the event. Another prominent example was the fourteenth Biennial, which was overambitious in its claims of being 'the most dispersed' edition. Although adding another area of touristic attraction to the Biennial repertoire, the Prince's Islands, more than some of the locations, were inaccessible and most of the venues were centrally placed. In a city such as Istanbul, where a population of fifteen million live in forty districts, it is of critical importance to aim for the equal dispersion of the exhibitions in the city, which would enable the Biennial to speak to different audiences and create a space for the unexpected encounters with art, the city and political discussion (Özpınar 2011: 273). However, this aspect of the Biennial should be interpreted with caution, 
as introducing the visitors to new locations or art through encounters may evoke associations to the 'art for the public good' and a top-bottom approach (Karaca 2010: 245; Erek and Köksal 2014: 307). The idea of bringing new venues to the attention of the visitors may also act as a failed attempt in the interaction with the specificities of different audience groups or the residents of the city in addition to turning the (contested) histories of the venues into a biennial extravaganza.

\section{Public space refashioned: Gentrification, consumption and the biennial}

These questions present yet another one with respect to the venues and locations of the Biennial, which points out the effects of the venue and location choices of the Biennial on Istanbul's urban renewal through the years. It is important to note that, similar to the protests that the thirteenth edition faced, the Biennial was vigorously challenged just a few years ago when it announced that Koç Holding, the Turkish industry giant, would sponsor the Biennial until 2026. As the Holding's association with the urban renewal process in Istanbul was widely known, a group of artists and activists who attempted to expose the entangled ties of the main biennial sponsor with the political dicta of the army in the 1980s reacted against this cooperation with a series of artistic interventions initiated a few weeks before the opening of the eleventh edition (Harutyunyan et al. 2011: 488-91). Calling themselves the Direnal ('Resist-take back') Collective, while challenging the conceptual framework that overtly referred to Marxist-Communist politics, their open letter that was published online, further 
exposing the institutional discourse of the Biennial, pointed to the destruction of the urban public space in Istanbul against the backdrop of neo-liberal hegemony and gentrification (Direnistanbul 2009; Harutyunyan et al. 2011: 489). In 2010, Gail Day, Steve Edwards and David Mabb published an article in which they elaborately discussed the political threads of the eleventh Biennial (2010: 148, 155-57). Day et al. (2010) labelled the argument of the protesters as 'stultifyingly one-dimensional' and dismissive of new forms of 'critical art' and new roles of aesthetic-political praxis on the grounds of being the 'paradox of avant-garde rhetoric (of merging with life)'. However, further investigation should be undertaken about gentrification in Istanbul to understand Direnal's protest to understand effects not only on the city but also on the way in which the Biennial regulates its audiences.

In her analysis of the causes and effects of gentrification, Sharon Zukin (1987: 143-44) discusses the issue of gentrification in the context of the city of New York. She identifies gentrification 'as a multidimensional cultural practice' that indicates 'a high-status cultural consumption and the colonization of an expanding terrain by economic institutions associated with the service sector'. As a 'means of social reproduction for part of the highly educated middle class', Zukin observes that cultural centres remain the only public places where the mobilized urban groups can gather to express their identities while overcoming the alienation effect generated by the big city (Zukin cited in Yardımc1 2005: 134). In the same vein, a few years later, in her article that addresses the transformation in urban lifestyles, Zukin (1998) 
argued that the interaction of the urban middle-class groups to culture has changed into 'an aggressive pursuit of cultural capital $[\ldots]$ that encourages various forms of cultural consumption' (Figure 12).

In this respect, the upper/upper-middle classes living in Istanbul are comparable to the ones in New York. In her analysis of the behaviour of urban groups in relation to the globalizing and gentrifying Istanbul, Asu Aksoy identifies this similarity. According to Aksoy (2008: 7980), two new elite middle-class groups, 'the post-1980s generation of secular, middle-class and professional workers' and the innovative 'Islamic-oriented traditional circles', although previously 'polarized', have recently started to share 'a common inspiration [...] a vision of Istanbul as a city that is globalised and gentrified, providing orderly and cleaned-up public spaces and residential quarters, with an attractive public image, world-class services and goods'. This view is also supported by İhsan Bilgin, who observes that the more lifestyles and cultures in public domain are aligning with 'global businesses that develop and manage large swathes of public space' the more 'our public experience [has] a life of its own as part of a pre-designed consumption experience' (Bilgin cited in Aksoy 2008: 75). Considering all these arguments, it seems that, given the areas and the venues that different editions have occupied so far, it seems that the Biennial, if not temporarily, reproduces the urban public spaces for the consumption of the 'highly educated middle class' in Istanbul. 
Gentrification has been a growing urban development problem in Istanbul for decades. It is generally assumed to play a role in the management of diverse social segments in the city. According to Nilgün Ergun (2004: 391), by replacing the centrally located low-income groups with high-income groups and by extension, their lifestyles, gentrification has operated as the tool of neo-liberal consumerism in urban space. More importantly, the process of gentrification has been instrumental in moving not only the disadvantaged and low-income groups but also ethnically and racially 'unwanted' populations out of the city. Central locations such as Galata and Taksim thus not only witnessed the contemporary art displays of the Biennial but also the forced removal of Roma people and the gradual eviction of minority groups including Jewish, Armenian and Greek communities throughout the years (Karaca 2010: 246). The locations that the Istanbul Biennial has so far employed thus cannot be conceived of in isolation from the urban regeneration process and neither can its contribution to the process be ignored. In this respect, particularly the ninth edition, as previously mentioned, not only attempted to detach from the enduring exotic, oriental image of the Biennial reinscribed by the cultural heritage-heavy venues, opting for the central axis of Galata and Beyoğlu, as they were 'by that time among the most sanitized parts of Istanbul, and already thoroughly integrated into globalized cultural, leisure, and entertainment industries $[\ldots]$ concealing local conflicts in other nearby districts socially and spatially fragmented due to urban transformation' (Erek and Köksal 2014: 306). 
This study set out with the aim of assessing the importance of venue and location choices of the Istanbul Biennial in the reproduction, imagination and the transformation of the city, urban public space and the visitors. It strengthens the argument of previous studies that have noted the importance of the images created by employing the landmark spots and buildings of the city and buildings with panoramic qualities to reiterate the idea of the exotic, oriental Istanbul in the eyes of the viewers and, more importantly, the 'artscape'. Interestingly, the fact that the Istanbul Biennial uses a variety of venues and locations in the past 30 years instead of relying on a dedicated space has not only provided the visitors with an opportunity to encounter art but has also offered the possibility of revealing new areas and places within the city, unlocking stories, associations and questions with every new location. These places also enable the visitors to chart their own paths in the city and have their own singular Biennial experience instead of limiting them to predetermined routes. Moreover, while this aspect has provided it with a certain flexibility to take on diverse forms and techniques of display, it has also come with a social responsibility for interacting within urban public space. Creating the possibility of critical-political participation of different segments of the society to the 'open' urban public space positions the visitors not as mere viewers but as a part of the city, its urban public space and everyday life, a much-needed aspect, given the recent political tensions in Turkey. These findings have significant indications for the understanding of how to include diverse groups in the Biennial while challenging the pre-given 
segmentations of the urban regeneration process within the city. Continued efforts are needed to understand the specificities of different audiences and to take several courses of action for confronting the severe implications of the Biennial venues and locations on the reproduction of urban public space and the process of gentrification in Istanbul.

Figure Caption List

Figure 1: 1st Istanbul Biennial (1987). Hagia Eirene Church, Istanbul, 25 September-15 November. Courtesy of IKSV, Istanbul.

Figure 2: Daniel Buren and Jannis Kounellis, 1989. Installation, Süleymaniye Soup Kitchen, 2nd Istanbul Biennial. Courtesy of IKSV, Istanbul.

Figure 3: Gülsün Karamustafa, Neworientation, 1995. Installation, Former warehouse no.1, 4th Istanbul Biennial, Mixed media. Courtesy of IKSV, Istanbul.

Figure 4: Alberto Garutti, To Those Born Today, 2001. Installation, Bosporus Bridge, 7th Istanbul Biennial, Streetlights.

Figure 5: Gabriele Basilico, Poster for the 9th Istanbul Biennial, 2005. Courtesy of IKSV, Istanbul. 
Figure 6: Michael Blum, A Tribute to Safiye Behar, 2005. Installation, Deniz Palas, 9th

Istanbul Biennial, Mixed Media. Courtesy of IKSV, Istanbul.

Figure 7: Location map of the 9th Istanbul Biennial, 2005.

Figure 8: Location map of the 14th Istanbul Biennial, 2015.

Figure 9: Metin Deniz, 1989. Installation, Sultanahmet Square, 2nd Istanbul Biennial, Mixed Media. Courtesy of IKSV, Istanbul.

Figure 10: Doris Salcedo, Untitled, 2003. Installation, Karaköy, 8th Istanbul Biennial, 1550 wooden chairs. Courtesy of IKSV, Istanbul. Photo credit: Muammer Yanmaz.

Figure 11: Ugo Rondino, Where Do We Go From Here?, 1999. Installation, Taksim Square, 6th Istanbul Biennial, Neon lights. Courtesy of IKSV, Istanbul.

Figure 12: Adrian Villar Rojas, The Most Beautiful of All Mothers, 2015. Site-specific installation, Trotsky House, 14th Istanbul Biennial, Organic and inorganic materials. Courtesy of IKSV, Istanbul. Photo credit: Jorg Baumann.

\section{Acknowledgements}

I wish to thank Ezgi Arıduru, Dr Teresita Scalco and Bige Örer for commenting on the earlier versions of this article. Aspects of this research have been presented in conferences in Ankara (Bilkent), Paris (ENS, Artl@s Project) and Venice (IUAV), and published in Turkish and 
Italian in edited collections, newspapers and academic journals. I would like to thank the audiences of these conferences and the editors of the publications for their valuable comments. I am grateful to IKSV for providing the images. Finally, I would like to extend my gratitude to the editor of this special issue, Dr Sarena E. Abdullah.

\section{References}

Ahıska, Meltem (2005), Radyonun Sihirli Kapısı: Garbiyatçılık ve Politik Öznellik, Istanbul: Metis Publications.

Aksoy, Asu (2008), 'Istanbul's choice', Third Text, 22:1, pp. 71-83.

Anon. (2013), 'Urban renewal activists protest at Istanbul Biennial', http://bianet.org/english/culture/145359-urban-renewal-activists-protest-at-istanbul-biennial. Accessed 26 December 2017. 
Appadurai, Arjun (1996), Modernity at Large: Cultural Dimensions of Globalization, Minneapolis: University of Minnesota Press.

Biemann, Ursula (1997), 'KÜLTÜR', GeoBodies, https://www.geobodies.org/books-andtexts/kultur. Accessed 27 December 2017. 
Istanbul Biennial (1995), 'ORIENT/ATION - The vision of art in a paradoxical world', http://bienal.iksv.org/en/archive/biennialarchive/213. Accessed 20 December 2017.

Carmona, Matthew (2010), 'Contemporary public space: Critique and classification, part one: critique', Journal of Urban Design, 15:1, pp. 123-48.

Certeau, Michel de (1984), The Practice of Everyday Life, Berkeley: University of California Press.

Coates, Rebecca (2014), 'From the Margins to the Center: The São Paulo Biennial, the Biennale of Sydney, and the Istanbul Biennial', Museum Worlds, 2:1, pp. 113-132.

Day, Gail, Edwards, Steve and Mabb, David (2010), “"What Keeps Mankind Alive?”: The eleventh International Istanbul Biennial. Once more on aesthetics and politics', Historical Materialism, 18:4, pp. 135-71. 
Demos, T. J. (2009), 'Barbarity or socialism? On the 11th International Istanbul Biennial', Texte zur Kunst, 76: December, https://www.textezurkunst.de/76/barbarei-oder-sozialismus. Accessed 5 January 2018.

Direnistanbul (2009), 'Direnistanbul'dan Bienal'a Açık Mektup', Bianet, https://m.bianet.org/bianet/diger/116869-direnistanbul-dan-bienal-a-acik-mektup. Accessed 10 December 2017.

IKSV Official Website, (2017), 'Home page', http://www.iksv.org/en. Accessed 11 May 2018.

13th Istanbul Biennial (2013), '13th Istanbul Biennial conceptual framework - Mom, Am I Barbarian?', http://13b.iksv.org/en. Accessed 10 January 2018.

Erek, Ayşe N. and Köksal, Ayşe H. (2014), 'Relocating the arts in the New Istanbul: Urban imaginary as a contested zone', Visual Resources, 30:4, pp. 301-18.

Ergun, Nilgün (2004), 'Gentrification in Istanbul', Cities, 21:5, pp. 391-405. 
Habermas, Jürgen (1991), The Structural Transformation of The Public Space - An Inquiry into a Category of Bourgeois Society, Cambridge, MA: The MIT Press.

Harutyunyan, Angela, Özgün, Aras and Goodfield, Eric (2011), 'Event and counter-event: The political economy of the Istanbul biennial and its excesses', Rethinking Marxism, 23:4, pp. 478-95.

Karaca, Banu (2010), 'The politics of urban arts events: A comparison of Istanbul and Berlin', in D. Göktürk, L. Soysal and İ. Türeli (eds), Orienting Istanbul: Cultural Capital of Europe?, London and New York: Routledge, pp. 234-50.

Kolatan, Sulan (1995), 'Touring Istanbul', in S. Vogel (ed.), 4th International Istanbul Biennial - The Vision of Art in a Paradoxical World (trans. Zeynep Rona), Istanbul: Istanbul Foundation for Culture and Arts, pp. 46-49. 
Kortun, Vasıf (2018), ‘1990’lar Üzerine Yeniden Düşünüş’, in B. Çaka (ed.), 20, Istanbul:

SALT/Garanti Kültür AŞ, pp. 11-46.

Madra, Beral (2003), Íki Yılda Bir Sanat, Istanbul: Norgunk Publications.

Madra, Yahya (2006), 'From imperialism to transnational capitalism: The Venice Biennial as

a "Transitional Conjuncture", Rethinking Marxism, 18:4, pp. 525-37.

Mouffe, Chantal (2005), On the Political, Abingdon: Routledge.

(2007), 'Art and democracy: Art as an agonistic intervention in public space', Open!, http://onlineopen.org/art-and-democracy. Accessed 9 January 2018.

Özbek, Meral (2004), 'Giriş: Kamusal Alan-Özel Alan, Kültür ve Tecrübe’, in M. Özbek (ed.), Kamusal Alan, Istanbul: Hil Press, pp. 443-500. 
Özpınar, Ceren (2011), 'Birey, Kent ve Kamusal Mekan Bağlamında İstanbul Bienali’, Kült Cultural Studies Journal, II:III, pp. 263-83.

(2013), 'Hangi Kamusal Alan?', Sanat Dünyamız, 133, pp. 110-12.

(2015), 'La Biennale di Istanbul', in T. Scalco and M. Valeri (eds), Ritratti di Città:

Istanbul, Bologna: Editrice Compositori, p. 96.

(2016), Türkiye'de Sanat Tarihi Yazımı, 1970-2010, Istanbul: History Foundation

Publications. 
Özpınar, Ceren. Başaran, Pelin. Aysun, Esra, Manukyan, Ayda and Uysal, Şafak (2011), 'Conditions for artistic creativity', in S. Ada (ed.), Turkish Cultural Policy Report-A Civil Perspective, Istanbul: Istanbul Bilgi University Press, pp. 213-20.

Pelvanoğlu, Burcu (2015), ‘'̇stanbul Bienalleri ve Mekânları - III’, Lebriz Sanal Dergi, 24 November, http://lebriz.com/pages/lsd.aspx?lang=TR\&sectionID=12\&articleID=1326. Accessed 19 March 2018.

Tang, Jeannine (2007), 'Of biennials and biennialists: Venice, Documenta, Münster', Theory Culture Society, 24: 7-8, pp. 247-60.

Tanyeli, Uğur (2007), 'Kamusal Mekan - Özel Mekan Türkiye’de Bir Kavram Çiftinin İcadı', Boyut Pedia, http://www.boyutpedia.com/1941/66973/kamusal-mekan-ozel-mekan-turkiyede-bir-kavram-ciftinin-icadi. Accessed 19 December 2017. 
Üner Y1lmaz, Pınar (2016), '14th Istanbul Biennial: Saltwater dissolves fiction in the truth of desolation', ArtSlant, https://www.artslant.com/ny/articles/show/43902-14th-istanbulbiennial-saltwater-dissolves-fiction-in-the-truth-of-desolation. Accessed 20 December 2017.

Wu, Chin-Tao (2009), 'Biennials without borders?', New Left Review, 57: May-June, pp. 107-15. (2010), 'Biennials and art fairs', Grove Art Online,

http://www.oxfordartonline.com/groveart/view/10.1093/gao/9781884446054.001.0001/oao9781884446054-e-7002086262. Accessed 15 December 2017.

Yardımc1, Sibel (2005), Kentsel Değişim ve Festivalizm: Küreselleşen İstanbul'da Bienal, Istanbul: İletişim Publications. 
(2007), 'Festivalising difference: Privatisation of culture and symbolic exclusion of

Istanbul', EUI Working Paper Series-RSCAS 2007/35, Badia Fiesolana: European

University Institute-Mediterranean Programme Series.

Zukin, Sharon (1987), 'Gentrification: Culture and capital in the urban core', Annual Review of Sociology, 13:1, pp. 129-47.

(1996), The Cultures of Cities, New York: Blackwell.

(1998), 'Urban lifestyles: Diversity and standardisation in spaces of consumption',

Urban Studies, 35:5\&6, pp. 825-39.

\section{Contributor details}

Ceren Özpınar is a lecturer at the University of Brighton, School of Humanities. She received her PhD in History of Art from Istanbul Technical University in 2015. Özpınar's research focuses on feminist art histories, art historiography, contemporary art and biennials. She is the author of the book The Art Historiography in Turkey (1970-2010), published in 2016 by 
the History Foundation in Turkish. Özpınar's recent articles appeared in journals including Art in Translation and Art Journal.

Contact: c.ozpinar@brighton.ac.uk

University of Brighton, College of Arts and Humanities, 10-11 Pavilion Parade, Brighton BN2 1RA

Note

${ }^{1}$ Eczacıbaşı Company later acquired one of the old warehouses on Bosporus and turned it into the Istanbul Museum of Modern Art in 2004. 